\title{
Preventing unintended teenage pregnancies and reducing their adverse effects
}

\author{
Deirdre Fullerton, Rumona Dickson, Alison J Eastwood, Trevor A Sheldon
}

\section{Introduction}

This paper summarises the results of a systematic review of the research evidence on approaches to preventing teenage pregnancy and alleviating the direct negative health and social effects of teenage pregnancy. It is based on an issue of Effective Health Care, Vol 3, No $1,{ }^{1}$ and full details of the systematic review are available elsewhere. ${ }^{2}$

The United Kingdom has the highest teenage pregnancy rate among 15-19 year olds in Western Europe. However, the rate of conceptions in the 16-19 year old age group has been decreasing since 1990 and the rate is currently 56.8 per 1000 . In the under 16 year olds the rate has been steady over the past 20 years ${ }^{3}$ despite evidence that young people are starting intercourse at an earlier age. ${ }^{4}$

In England and Wales, the Health of the Nation strategy has identified the prevention of pregnancy in under 16 year olds as a priority area, with a target to reduce the rate of conceptions from 9.6 per 1000 in 1989 to 4.8 per 1000 by the year $2000 .^{5}$ The most recent figures show that the rate of conceptions in under 16 year olds is currently at 8.3 per $1000 .^{3}$ This rate varies across districts, ranging from 4.2 to 19.3 per 1000 in 1993 .

For many young women pregnancy and motherhood are positive and welcomed experiences without long term negative outcomes. ${ }^{7-9}$ However, compared with women aged 20 to 35 , teenagers are at higher risk of experiencing adverse health, and more importantly, educational, social, and economic outcomes (table 1)..$^{10-17}$ Teenage pregnancies may also result in significant public costs. ${ }^{18} 19$

About half of the pregnancies among under 16 year olds and a third of the pregnancies among 16-19 year olds are terminated. ${ }^{3}$ These terminations can have an adverse effect on the health of teenagers. Pregnant teenagers who have a miscarriage may also suffer due to inadequate support.

Several factors are associated with early sexual initiation, non-use of contraception, and teenage pregnancy. These include social influences, health service, and socioeconomic factors, as well as individual characteristics. Pregnancy rates are higher in more socially deprived areas and in areas with less public welfare services, and the proportion of pregnancies terminated are lower. ${ }^{20-23}$ The associated burden of unintended pregnancy may therefore be greater in poorer localities. Particular groups at increased risk of pregnancy during the teenage years include daughters of teenage mothers, young people "looked after" by the local authority and leaving care, school non-attendees due to truancy or exclusion, and homeless or runaway teenagers.

\section{Methods}

The overview of research evidence identified systematic reviews of teenage pregnancy prevention programmes, and systematic reviews of the programmes aimed at preventing adverse outcomes associated with teenage parenthood. Also, in the area of prevention of teenage pregnancy, additional services were carried out to identify other quantitative and qualitative primary studies.

Reviews and primary studies were identified by searches of computerised databases (Medline, Embase, Social Science Citation Index, PsycLit, DHSS database, Cochrane Database of Systematic Reviews), citations in identified papers and previous reviews, and contributions from peer reviewers and other experts in the field.

The main criteria for inclusion of the reviews were that they had a focus on prevention of pregnancy among 13-19 year olds or the adverse outcomes associated with teenage pregnancy, and that they were systematic in their identification, assessment, and pooling of the primary studies. Two reviewers extracted the details from each review with a standard form. Additional primary studies not included in the quality reviews were assessed from structured guidelines. ${ }^{24}$

\section{Results}

EDUCATIONAI APPROACHES TO PREVENTION A total of 45 reviews of research in the area of teenage pregnancy were identified, of which five were considered to be relevant and of high quality. An additional four reviews included important source material. ${ }^{25-28}$ These reviews, together with additional searches, identified 42 
Table 1 Adverse outcomes associated with pregnancy for the teenager and her child

\begin{tabular}{|c|c|c|c|}
\hline & Health outcomes & Educational outcomes & Social economic outcomes \\
\hline Young woman & $\begin{array}{l}\text { Hypertension, anaemia, placental } \\
\text { abruption, obstetric complications, } \\
\text { depression and isolation }{ }^{10-14,91} \\
\text { Termination of pregnancy, distress } \\
\text { and depression }\end{array}$ & $\begin{array}{l}\text { School dropout and gaps in } \\
\text { education }{ }^{16,92}\end{array}$ & $\begin{array}{l}\text { Reduced employment opportunities. } \\
\text { Increased reliance on state welfare } \\
\text { Poor housing and nutrition }^{16,93,94}\end{array}$ \\
\hline Child & $\begin{array}{l}\text { Increased risk of sudden infant } \\
\text { syndrome, prematurity, admission to } \\
\text { hospital due to accidental injuries } \\
\text { Inc-97 } \\
\text { and of teenage pregnancy }{ }^{17,98,99}\end{array}$ & $\begin{array}{l}\text { In the preschool years } \\
\text { children of teenage mothers } \\
\text { display developmental } \\
\text { delays }^{97,100}\end{array}$ & Poor housing and nutrition ${ }^{93,94}$ \\
\hline
\end{tabular}

evaluations of educational approaches to preventing teenage pregnancy.

Most of the evaluations of educational approaches to prevent teenage pregnancy have been conducted in the United States and are principally comparisons of new methods of sex education compared with those programmes which are routinely provided. Table 2 provides a summary of those evaluations which used a randomised controlled trial research design.

Four school based educational models have been evaluated: abstinence programmes, building skills combined with factual information, school based programmes that are linked with contraceptive services, and school linked sex education programmes that also encourage vocational development. Additional education approaches include one to one counselling within healthcare settings. We summarise the key results, in order of increasing complexity, with special emphasis on the results from the better quality studies.

\section{Abstinence programmes}

The main aim of abstinence based programmes is to delay sexual activity until later in the teenage years or until marriage. Such programmes generally develop decision making and refusal skills, and rarely provide information on contraceptive methods or contraceptive services. When compared with the usual sex education, abstinence programmes were not found to have any additional effect in either delaying sexual activity or reducing pregnancy. ${ }^{2930}$

\section{School based building skills combined with factual information}

Programmes which emphasise the postponement of sexual activity, through the development of more complex skills than in abstinence programmes combined with factual information on contraceptives and where to get them, have had some success in changing young people's sexual and contraceptive behaviours. ${ }^{31-33}$ Omitting guidance on contraceptives and where to get them seems to be less effective. ${ }^{34}$

Programmes encouraging vocational development Programmes which increase life options by providing guidance, encouragement, or support to complete education or improve job prospects may help motivate young people to avoid pregnancy. Several programmes which combine sex education with career planning or work experience during the summer holidays have shown some success in increasing contra- ceptive use ${ }^{35-37}$ and reducing pregnancy rates. ${ }^{38}$ However, it is difficult to identify the separate contribution of vocational training.

\section{School based programmes linked with} contraceptive services

Programmes which combine sex education with access to contraceptive services have proved effective in increasing contraceptive use. ${ }^{39}{ }^{40}$ One multifaceted community approach combined peer led skills and confidence building programmes and access to condoms and transport to contraception clinics. Follow up of the community programme at 24 months found a significant reduction of pregnancies. ${ }^{3941}$ Longer term follow up found that after local legislation prohibited the provision of contraceptives from school clinics, the pregnancy rate returned to preprogramme levels. ${ }^{39}$

\section{School based and school linked clinics}

Evaluations of school based clinics providing health and contraceptive services in the United States have been methodologically weak, with poor selection of comparison groups, and the results are contradictory. Some show delay in sexual initiation ${ }^{42}$ and reduction in birth rate, ${ }^{43}$ but no changes in contraceptive use. ${ }^{4244}$

A promising United Kingdom multidisciplinary project of teachers, school nurse, and contraceptive clinic staff, based on a Swedish prototype with school education combined with group visits to local clinics, has yet to be fully evaluated. ${ }^{45}$

\section{Features associated with successful education programmes}

Despite the variety of the different approaches used in the delivery of sex education programmes, some general lessons emerge. Importantly, there is consistent evidence that providing sex and contraceptive education within school settings does not lead to an increase in sexual activity or incidence of pregnancy. ${ }^{46-52}$ Indeed, the provision of clear information about contraceptive methods and how and when to access contraceptive services seems important to the success of educational programmes.

The timing of these educational programmes also seems to be important: young people who are already sexually active at the start of the interventions, for example, are less likely to change their sexual and contraceptive behaviour. As young people are not homogenous, programmes should be tailored to the group it serves. 
Those few studies which have shown a reduction of teenage pregnancy provided multifaceted programmes with links to contraceptive services or work experience. However, the lack of evidence of effectiveness of other approaches in reducing pregnancy rates may be due to the fact that most of the studies did not have appropriate comparison groups, large enough sample sizes, or long enough follow up to detect significant effects.

Most of the evaluated programmes have focused on considering the individual factors associated with teenage pregnancy, and have shown some success. However, few programmes have attempted to tackle underlying social, economic, and other environmental factors associated with increased risk of pregnancy.

\section{CONTRACEPTIVE SERVICE DELIVERY}

Cost effectiveness of contraceptive services

Contraceptives, when used properly, are highly effective at preventing pregnancy. Recent economic evaluations have shown that family planning services are also highly cost effective and provide a high rate of return to the National Health Service. ${ }^{1953}$ When the resource consequences of pregnancy are taken into account, family planning provision of contraceptive services to a teenager is calculated to save $£ 377$ per unwanted pregnancy avoided, and provision of oral contraception by the general practitioner saves $£ 466$ per unplanned pregnancy avoided when compared with no service. The economic benefit:cost ratio of family planning provision is even higher if the economic implications of health gains other than avoided unplanned pregnancy are included and if the averted costs generated by the children arising from unplanned pregnancies are included. ${ }^{54}$

\section{Effectiveness of different ways of delivering contraceptive services}

Surveys show that there is great variation in the types of services provided, their management and accessibility, and how well equipped they are. ${ }^{55-59}$

Correlational studies show an association between conception rates and the level and type of contraceptive services available locally. ${ }^{60}$ The effect of these services in terms of use and pregnancy rates seems to be stronger when they are provided by general clinics ${ }^{6162}$ or youth oriented clinics. $^{6364}$ However, expanding the supply of contraceptive services without a corresponding increase in demand-for example, by education - has not always been effective. ${ }^{65}$

The literature searches, however, showed that in the United Kingdom there is a complete lack of controlled evaluations of the effectiveness or cost effectiveness of different approaches to the delivery of contraceptive services to young people. Studies in the United Kingdom have been restricted to less reliable before and after studies of conception rates, ${ }^{66-68}$ audits of use of services, and qualitative studies of users and potential users. ${ }^{69} 70$ Two recent United Kingdom reviews provide valuable information on delivery of contraceptive services. $^{2728}$
In the absence of clear evidence it seems sensible to develop services in the light of the more descriptive studies. A review of descriptive United Kingdom studies which examined factors likely to influence the effectiveness of services was carried out. ${ }^{2}$ Eighty eight primary studies of young people's needs, use, or experience of contraceptive services were identified. These indicated that services should take into account in a systematic way local circumstances and needs. ${ }^{71} \mathrm{~A}$ recent national survey of providers of sexual health services, however, found that few agencies undertake systematic local needs assessments before the development of services. ${ }^{28}$

To attract young people to use services, they need to be well advertised, easily accessed outside school hours (opening times and location), informal, and for under 16 year olds, confidential. ${ }^{72}$ They should be developed in collaboration with key statutory agencies, relevant voluntary groups and community groups; should be broad based, and staffed by people trained to work with young people. ${ }^{73-77}$

\section{PREVENTING ADVERSE HEALTH AND SOCIAL} OUTCOMES

Given that half of the under 16 year olds and two thirds of 16-19 year olds continue with their pregnancies it is important to explore ways in which health, educational, and social services can intervene effectively to promote the health and wellbeing of teenage parents and their children.

\section{Antenatal care}

Several reliable studies have shown that good antenatal care is associated with improved pregnancy outcomes for teenagers, as well as older women. ${ }^{7879}$ However, teenage girls' ambivalence about their pregnancy or fear of discovery may delay or prevent their uptake of antenatal care. ${ }^{80} \mathrm{~A}$ recent meta-analysis of antenatal care programmes for pregnant teenagers, found consistent evidence for the effectiveness of comprehensive programmes in reducing poor maternal outcomes. ${ }^{11}$ These may also save resources for health, education, and social services.

\section{Social support and parenting}

Two recent reviews of the randomised controlled trials of home visiting and psychological support for disadvantaged mothers concluded that such programmes have the potential to reduce significantly the incidence of babies with incomplete immunisation, with severe nappy rash, admission to hospital during the first year of life, childhood injury, or being suspected victims of child abuse. ${ }^{81}{ }^{82}$ Home based parenting support programmes have been found to be effective in improving the teenage mother's interaction with her child or enhancing the infant's development. ${ }^{83}$

In the United Kingdom there are several voluntary organisations and programmes which provide support for young families under stress, such as Homestart and Newpin. 


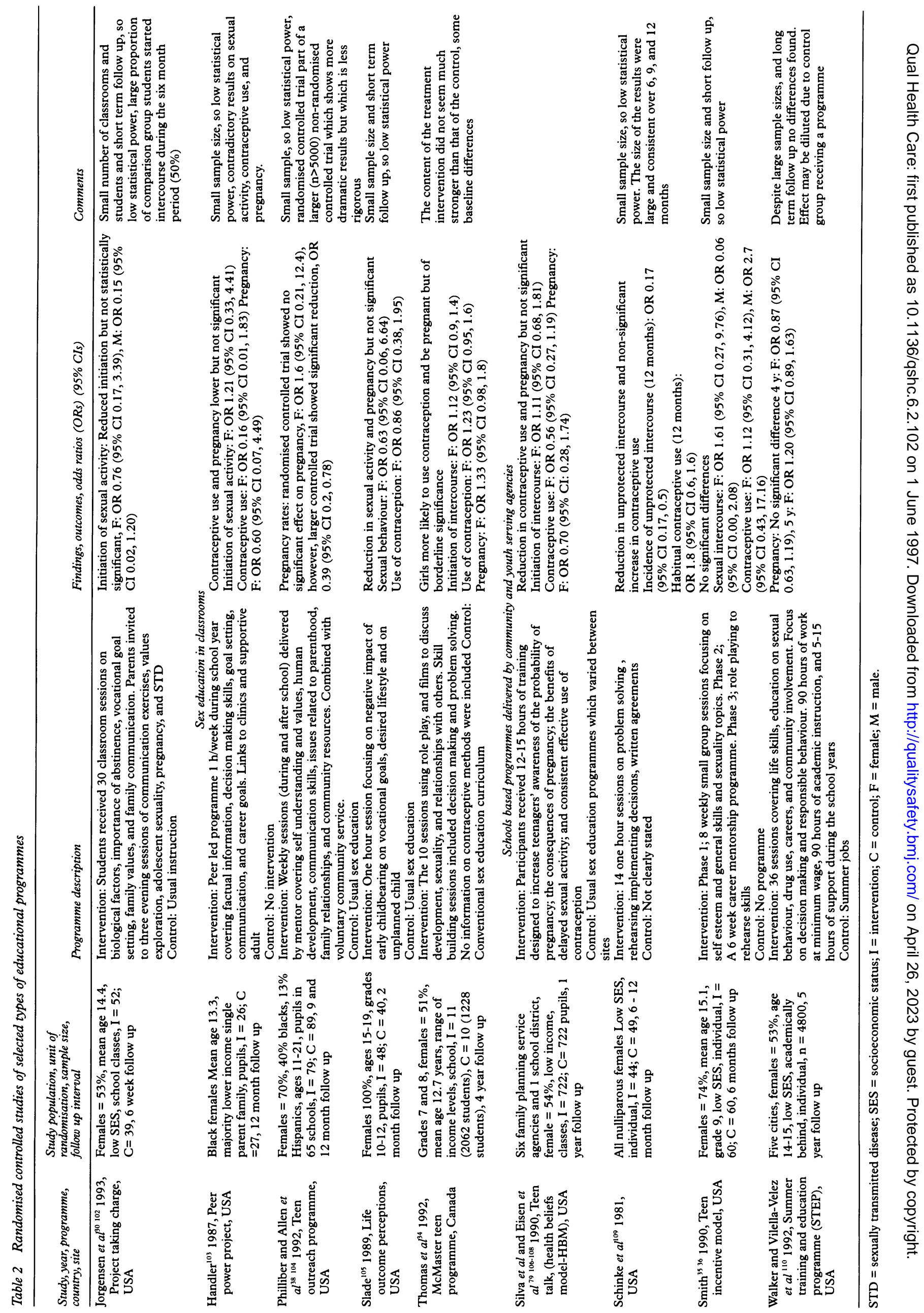


However, there is no evidence from rigorous studies of their long term effect on health and social outcomes. ${ }^{84-86}$

\section{Preschool education and support}

Parenting skills programmes or support to continue formal education have been shown to improve teenage mother-child interaction, and enhance child development. ${ }^{83}$ Early education programmes of good quality can improve longer term outcomes for disadvantaged children. A meta-analysis of evaluations of preschool programmes for low income families found that they performed better at school. ${ }^{87}$

Long term evaluations of Project Head Start, a United States project aimed at breaking the cycle of poverty by providing preschool education to children from disadvantaged communities have reported gains in children's cognitive ability, self esteem, school attainment, motivation, and social behaviour. $^{88} 89$

\section{Parental education support}

As well as day care, there are several approaches which provide the opportunity to continue formal education. These include free standing programmes which offer young teenagers general curriculum education together with education courses relevant to childbearing and parenting (and in some cases also provide child care); supplementary programmes provided within the mainstream school system with courses relevant to teenage parents, and home one to one tutoring. A recent survey found that $60 \%$ of local educational authorities provided special centres for schoolgirl mothers. ${ }^{90}$

\section{Conclusions}

Because of the complex range of individual, social, and economic factors, multifaceted approaches involving local people, education, health, and social services are important. General antipoverty strategies are likely to influence rates of teenage pregnancies and help to reduce adverse outcomes. Also specific interventions including the provision of supplementary nutrition, social support, educational opportunities, and preschool education, are likely to be effective. Parenting skills programmes and support for young mothers to continue formal education should be developed.

School based sex education plays an important part in the prevention of teenage pregnancy, and is most effective when linked with contraceptive services and building up skills started before young people become sexually active. Young peoples' perceived barriers to services might be overcome through clinic staff or general practitioner visits to schools and youth settings, or through school visits to the contraceptive service.

Contraceptive services should be developed in the light of an assessment of the needs of the community it serves. Contraceptive service providers should ensure and publicise easy access-for example, opening times outside school hours and at weekends-and confidentiality for young people. Specialised antenatal care programmes for pregnant teenagers involving, for example, general practitioners, district nurses, health visitors, and social workers are likely to improve health outcomes.

A coordinated programme of rigorous research is needed to evaluate the effectiveness of the different approaches to delivery of contraceptive services in reducing unintended pregnancy among young people.

We acknowledge the support of staff of the NHS Centre for Reviews and Dissemination Information Service in helping to develop the search strategy and in the identification of relevant literature. The Centre is funded by the NHS Executive and the Health Departments of Scotland, Wales, and Northern Ireland. The views expressed in this publication are those of the authors.

1 NHS Centre for Reviews and Dissemination. Preventing and reducing the adverse effects of unintended teenage pregnancies. Effective Health Care 1997;3:1-12.

2 NHS Centre for Reviews and Dissemination. Preventing and reducing the adverse effects of unintended teenage pregnancies. York: NHS Centre for Reviews and Dissemination, 1997. (CRD report 9 .)

3 Office for National Statistics. Birth statistics. London HMSO, 1996. (FM1 no 23.)

4 Johnson AM, Wadsworth J, Wellings K, Field J, Bradsay S. Sexual attitudes and lifestyles. London: Blackwell Scientific, 1994.

5 Department of Health. Health of the Nation: a strategy for health in England. London: HMSO, 1992.

6 Office of Population Censuses and Surveys. Public health standard dataset London: HMSO, 1993

7 Phoenix A. Young mothers, Oxford: Polity Press, 1991.

8 Hudson F, Ineichen B. Taking it lying down: sexuality and teenage pregnancy. Basingstoke: MacMillan, 1991.

$9 \mathrm{Oz} \mathrm{S}$, Fine M. A comparison of childhood backgrounds of teenage mothers and their non-mother peers: a new formulation. $\mathcal{F}$ Adolesc Health 1988;11:251-61.

10 Elliott $\mathrm{H}$, Beazley J. A medical study of pregnancy in Liverpool. F Obstet Gynaecol 1980;1:139-43.

11 Scholl TO, Hediger ML, Belsky DH. Prenatal care and maternal health during adolescent pregnancy: a review and meta-analysis. $\mathcal{F}$ Adolesc Health 1994;15:444-56.

12 Leppert PC, Namerow PB, Baker D. Pregnancy outcomes among adolescent and older women receiving comprehensive prenatal care. $\mathcal{f}$ Adolesc Health Care 1986;7:112-7.

13 Konje JC, Palmer A, Watson A, Hay DM, Imrie A, Ewings P. Early teenage pregnancies in Hull. Brf Obstet Gynaecol 1992;99:969-73.

14 Wolkind $S$, Kruk $S$. Teenage pregnancy and motherhood. $\mathcal{f}$ R Soc Med 1985;78:112-6.

15 Wolfe B, Perozek M. Health and medical care costs to society of teen pregnancy: children from birth to age 14. Wisconsin Institute for Research and Poverty, University of Wisconsin, 1995. (Discussion paper 1072.)

16 Wellings K, Wadsworth J, Johnson A, Field J. Teenage sexual ity, fertility, and life chances: a report prepared for the Department of Health using data from the national survey of sexual ment of Health using data from the national survey of sexual attitudes and lifestyles. London:

17 Kiernan K. Transition to parenthood: young mothers, young fathers - associated factors and later life experiences. London London School of Economics, 1995. (Welfare State Programme Discussion Paper 113.)

18 Burt MR. Estimating the public costs of teenage childbearing. Fam Plann Perspect 1986;18:221-6.

19 McGuire A, Hughes D. The economics of family planning services. A report prepared for the Contraception Alliance London: Family Planning Association, 1995.

20 Zimmerman SL. State level public policy choices as predictors of state teen pregnancies. Family Relations 1988 37:315-21.

21 Smith $\mathrm{T}$. Influence of socioeconomic factors on attaining targets for reducing teenage pregnancies. BMF 1993 306:1232-5.

22 Wilson SH, Brown TP, Richards RG. Teenage conception and contraception in English regions. $\mathcal{f}$ Public Health Med 1992;14:17-25.

23 Garlick R, Ineichen B, Hudson F. The UPA score and teenage pregnancy. Public Health 1993;107:135-9.

24 NHS Centre for Reviews and Dissemination. Undertaking systematic reviews of research on effectiveness. CRD guidelines for those carrying out or commissioning reviews. York: NHS for those carrying out or commissioning reviews. York: NHS
Centre for Reviews and Dissemination, 1996. (CRD report 4.)

25 Hayes CD, ed. Risking the future: adolescent sexuality, pregnancy, and childbearing. Vol I. Washington, DC: pregnancy, and childbearing.
National Academy Press, 1987.

26 Moore KA, Miller BC, Glei DA, Morrison DR. Adolescent sex, contraception, and childbearing: a review of recent research. Washington, DC: Child Trends, 1995. 
27 Peach E, Harris J, Bielby E. Teenage pregnancy: a community issue: a literature review. Leeds: Nuffield Institute for issue: a literature review. Leeds:
Health, University of Leeds, 1994.

28 Peckham S, Ingham R, Diamond I. Teenage pregnancy: prevention and programmes. Southampton: Institute for Health Policy Studies, University of Southampton, 1996. pregnancy prevention program: is "just say no" enough?
Family Relations 1990;39:68-72.

30 Jorgensen SR. Project taking charge: an evaluation of an adolescent pregnancy prevention program. Family Relations 1991;40:373-80.

31 Barth RP, Fetro JV, Leland NL, Volkan K. Preventing adolescent pregnancy with social and cognitive skills. Fournal of Adolescent Research 1992;7:208-32.

32 Howard M, McCabe JB. An information and skills approach for younger teens: postponing sexual involvement program. In: Miller B, Card J, Paikoff R, Peterson J, eds. Preventing adolescent pregnancy: model programs and evaluations. Newbury Park, CA: Sage, 1992.

33 Mellanby AR, Phelps FA, Crichton NJ, Tripp JH. School sex education: an experimental programme with educational and medical benefit. $B M F$ 1995;311:414-7.

34 Thomas BH, Mitchell A, Devlin C, Goldsmith C, Singer J, Watters D. The small group sex education at school: the McMasters team program. In: Miller BC, Card JJ, Paikoff RL, Peterson JL, eds. Preventing adolescent pregnancy: models programs and evaluations. Newbury Park, CA: Sage, 1992.

35 Smith MA. Teen incentives program: evaluation of a health promotion model for adolescent pregnancy prevention. promotion model for adolescent pregna

36 Smith MAB. The teen incentive program: a research and evaluation model for adolescent pregnancy prevention. New York: Columbia University, 1990.

37 Nicholson HJ, Postrado LT. A comprehensive age phased approach: girls incorporated. In: Miller BC, Card JJ, Paikoff RL, Peterson JL, eds. Preventing adolescent pregnancy: model programs and evaluations. Newbury Park, CA: Sage, 1992 .

38 Philliber S, Allen JP. Life options and community service: teen outreach program. In: Miller BC, Card JJ, Paikoff RL, teen outreach program. In: Miller BC, Card J, Paikoff RL, Peterson JL, eds. Preventing adolescent pregnancy: models
programs and evaluations. Newbury Park, CA: Sage, 1992.

39 Koo HP, Dunteman GH, George C, Green Y, Vincent M Reducing adolescent pregnancy through a school and community based intervention: Denmark, South Carolina revisited. Fam Plann Perspect 1994;26:206-11.

40 Zabin LS, Hirsch MB, Smith EA, Streett R, Hardy JB. Evaluation of a pregnancy prevention program for urban teenagers. Fam Plann Perspect 1986;18:119-26.

41 Vincent ML, Clearie AF, Schluchter MD. Reducing adolescent pregnancy through school and community-based education. $¥ A M A$ 1987;257:3382-6.

42 Kisker EE. The effectiveness of family planning clinics in serving adolescents. Fam Plann Perspect 1984;16:212-8.

43 Ralph N, Edgington A. An evaluation of an adolescent fam ily planning program. $\mathcal{F}$ Adolesc Health Care 1983;4:15862.

44 Kirby D, Waszak C, Ziegler J. Six school-based clinics: their reproductive health services and impact on sexual behavior. Fam Plann Perspect 1991;23:6-16.

45 Jackson $P$, Plant $Z$. Youngsters get an introduction to sexual health clinics. Nursing Times 1996;92:34-6.

46 Oakley A, Fullerton D, Holland J, Arnold S, FranceDawson M, Kelley P, et al. Sexual health education interventions for young people: a methodological review. $B M \mathcal{F}$ 1995;310:158-62.

47 Peersman G, Oakley A, Oliver S, Thomas J. Review of effectiveness of sexual health promotion interventions for young people. London: Social Science Research Unit, University of London, 1996.

48 Kirby D, Short L, Collins J, Rugg D, Howard M, Miller B, et al. School-based programs to reduce sexual risk behaviors: a review of effectiveness. Public Health Rep 1994; 109:339-61

49 Kirby D. A review of educational programs designed to reduce sexual risk-taking behaviors among school-age youth in the United States. Washington, DC: US Congress Office of Technology Assessment, 1995.

50 Frost JJ, Forrest JD. Understanding the impact of effective teenage pregnancy pre

51 DiCenso A. Systematic overviews of the prevention and predictors of adolescent pregnancy [PhD thesis]. Ontario: predictors of adolescent preg
University of Waterloo, 1995.

52 Stout JW, Rivara FP. Schools and sex education: does it work? Pediatrics 1989;83:375-9.

53 Trussell J, Leveeque JA, Koenig JD, London R, Borden S, Henneberry J, et al. The economic value of contraception: a comparison of 15 methods. Am $\mathcal{f}$ Public Health 1995;85:494-503.

54 Hughes D, McGuire A. The cost-effectiveness of family planning $\mathrm{s}$

55 Cooper P, Diamond I, High S, Pearson S. The provision of family planning services by family planning clinics: a social family planning services by family planning clinics: a social tistics, University of Southampton, 1992.

56 Cooper P, Diamond I, High S, Pearson S. The provision of family planning services by general practitioners: a social survey in Wessex. Southampton: Department of Social Statistics, University of Southampton, 1992.
57 Family Planning Association. Sexual health and family planning services in general practice: report of a quantitative research survey in England and Wales. Family Planning Association, 1993.

58 Thompson E, Chapple J. Quality contraception or sexual health care? A survey of family planning clinic managers in one health region. British fournal of Family Planning 1993; 19:232-5.

59 Pitts M, Burtney E, Dobraszczyc U. "There is no shame in it anymore": how providers of sexual health advice view young people's sexuality. Health Education Research 1996;

60 Lundberg S, Plotnick RD. Adolescent premarital childbearing: do economic incentives matter? Fournal of Labor Economics 1995;13:177-200.

61 Allaby MK. Reviewing family planning services: a method for population based outcome related needs assessment. Br f Fam Plan 1993;18:102-5.

62 Allaby MA. Contraceptive services for teenagers: do we need family planning clinics? $B M F$ 1995;310:1641-3.

63 Clements S, Diamond I, Ingham R, Stone N. Teenage conceptions in the Isle of Wight. Southampton: Centre for Sexual Research, University of Southampton, 1996.

64 Stone N, Clements S, Ingham R, Diamond A. Modelling the spatial distribution of teenage conception rates within Wessex. Report for the regional research and development sexual health programme. Southampton: Centre for Sexual Health Research, University of Southampton, 1996.

65 Hughes M, Furstenberg FF, Jr. The impact of an increase in family planning services on the teenage population of Philadelphia. Fam Plann Perspect 1995;27:60-65,78.

66 Allen I. Family planning and pregnancy counselling projects for young people London: Policy Studies Institute, 1991.

67 Withnell S. An evaluation of the young people's drop-in at Newport Pagnall Health Centre: the first twelve months. Aylesbury, Buckinghamshire Health Authority, 1994.

68 Wilson S, Daniel S, Pearson J, Hopton C, Madeley R. An evaluation of a new teenage clinic and its impact on teenage conceptions in Nottingham from 1986 to 1992. Contraception 1994;50:77-86.

69 West J, Hudson F, Levitas R, Guy W. Young people and clinics: providing for sexual health in Avon. Bristol: Department of Sociology, University of Bristol, 1995.

70 Cooper P, Diamond I, Gould C, High S, Schlamm E. The use, users and sources of contraception in the UK: a literature review. Southampton: Department of Social Statistics, University of Southampton, 1992.

71 Ubido J, Ashton J. Small area analysis: abortion statistics. $\mathcal{F}$ Public Health Med 1993;15:137-43.

72 British Medical Association. Confidentiality and people under 16. London: Health Education Authority, 1993.

73 Cooper P, Diamond I, High S. Choosing and using contraceptives: integrating qualitative and quantitative methods in family planning. Fournal of the Market Research Society 1993;35:325-39.

74 Pearson VA, Owen MR, Philips DR, Gray DJ, Marshall $M N$. Teenage pregnancy: a comparative study of teenagers choosing termination of pregnancy or antenatal care. $\mathcal{F} R$ Soc Med 1995;88:384-8.

75 Hill MR. Do family planning facilities meet the needs of the sexually active teenager? Br f Fam Plan 1987;13:143-51.

76 Penlington E, Tatman M. Health needs of adolescents in Coventry. Coventry: Child and Family Health Services, Coventry Healthcare NHS Trust, 1995.

77 Wareham V, Drummond N. Contraception use among teenagers seeking abortion: a survey from Grampian. Britteenagers seeking abortion: a survey from Gram
ish fournal of Family Planning 1994;20:76-8.

78 Singh S, Torres A, Forrest J. The need for prenatal care in the United States; evidence from the 1980 national natality survey. Fam Plann Perspect 1985;17:118-24.

79 Silva MO, Cabral H, Zuckerman B. Adolescent pregnancy in Portugal: effectiveness of continuity of care by an obstetrician. Obstet Gynecol 1993;81:142-6.

80 Stevens-Simon C. Care of pregnant teenagers in school. $\mathcal{f}$ Sch Health 1992;62:304-9.

81 Hodnett E. Support from caregivers for socially disadvantaged mothers. In: Enkin MW, Keirse MJNC, Renfrew MJ, Neilson JP, eds. Pregnancy and childbirth module of The Cochrane Database of Systematic Reviews, [updated 06 September 1996]. Available in The Cochrane Library [database on disk and CDROM]. The Cochrane Collaboration, issue 3 ed. Oxford: update software. London: BMJ Publishing Group, 1996.

82 Roberts I, Kramer MS, Suissa S. Does home visiting prevent childhood injury? A systematic review of randomised controlled trials. BMF 1996;312:29-33.

83 Panzarine $S$. Teen mothering: behaviors and interventions. $\mathcal{f}$ Adolesc Health Care 1988;9:443-8.

84 Oakley A, Rajan L, Turner H. An evaluation of NEWPIN. Report of work carried out 1994-5. London: Social Science Research Unit, University of London, 1995.

85 Rajan L, Turner H, Oakley A. A study of homestart. London: Social Science Research Unit, University of London, 1996.

86 Shinman SM. Family health and home-start. Information for commisioners and purchasers of family support services. commisioners and purchasers of

87 Darlington RB, Royce JM, Snipper AS, Murray HW, Lazar I. Preschool programs and later school competence of children from low-income families. Science 1980;208:202-4.

88 McKey HR, Condelli L, Ganson H, Barrett B, McConkey C, Plantz M. The impact of Head Start on children, families 
and communities. London: CSR incorporated, The Head Start Bureau, Administration for children, youth and families, 1985 .

89 Sylva K. School influences on children's development. $f$ Child Psychol Psychiatry 1994;35:135-70.

90 Dawson N. Educational provision for pregnant schoolgirls and schoolgirl mothers. Teenage Parenthood Network 1994 13:22-4.

91 Maskey S. Teenage pregnancy; doubts, uncertainities, and psychiatric disturbance. $\mathcal{F} R$ Soc Med 1991;84:723-5.

92 Upchurch DM, McCarthy JL. The timing of the first birth and high school completion. American Sociological Review 1990;55:224-34.

93 Simms M, Smith C. Teenage mothers and their partners: a survey in England and Wales. London: HMSO, 1986.

94 Williams S, Forbes JF, Mcllwaine GM, Rosenberg K. Poverty and teenage pregnancy. BMf 1987;294:20-1.

95 Murphy A. Cardiff birth survey. $f$ Epidemiol Community Health 1982;36:17-21.

96 Russell JK. Early teenage pregnancy. Edinburgh: Churchill Livingstone, 1982

97 McAnarney ER, Hendry L. Adolescent pregnancy and its consequences. $\mathcal{F A M A}$ 1989;262:74-7.

98 Burghes L, Brown M. Single lone mothers: problems, prospects, and policies. London: Family Policy Studies Centre, 1995.

$99 \mathrm{Di}$ Salvo P. Intergenerational patterns of teenage fertility in England and Wales [MSc thesis]. London: London School of Hygiene and Tropical Medicine, 1992.

100 Furstenberg FF, Brooks Gunn J, Morgan SP. Adolescent mothers and their children in later life. Fam Plann Perspect 1987;19:142-51
101 Clewell BC, Brooks Gunn J, Benasich AA. Evaluating child related outcomes of teenage parenting programs. Family Relations 1989;38:201-9.

102 Jorgensen SR, Potts V, Camp B. Project taking charge: 6 month follow up of a pregnancy prevention program fo early adolescents. Family Relations 1993;42:401-6.

103 Handler A. An evaluation of a school-based education pregnancy prevention program [ $\mathrm{PhD}$ thesis]. Illinois: University of Illinois, 1987.

104 Allen JP, Kuperminc G, Philliber S, Herre K. Programmatic prevention of adolescent problem behaviors: the role matic prevention of adolescent problem behaviors: the role of autonomy, relatedness, and volunteer services in the
Teen Outreach Program. Am f Community Psychol 1994;22:617-38

105 Slade LN. Life-outcome perceptions and adolescen contraceptive use [PhD thesis]. Atlanta, GA: Emory University, 1989.

106 Eisen M, Zellman GL, McAlister AL. A health belief model-social learning theory approach to adolescents' fertility control: findings from a controlled field trial. Health Educ Q 1992;19:249-62.

107 Eisen M, Zellman GL, McAlister AL. Evaluating the impact of a theory-based sexuality and contraceptive eduimpact of a theory-based sexuality and contraceptive

108 Eisen M, Zellman GL. A health beliefs field experiment teen talk. In: Miller BC, Card JJ, Paikoff BL, Peterson JL eds. Preventing adolescent pregnancy: model programs and evaluations. Newbury Park, CA: Sage, 1992.

109 Schinke SP, Blythe BJ, Gilchrist LD, Burt GA. Primary prevention of adolescent pregnancy. Social Work with Groups 1981;4:121-35.

110 Walker G, Vilella-Velez F. Anatomy of a demonstration. Philadelphia: Public/Private Ventures, 1992. 